\title{
INTERNET MARKETING COMMUNICATIONS: INTERACTIVITY AND INTEGRATION
}

\author{
BRETT LAWTON $^{1}$ and SHIRLEY GREGOR ${ }^{2}$ \\ ${ }^{I}$ Marketing Department, School of Business and Economics, University of Auckland, \\ New Zealand \\ ${ }^{2}$ School of Business and Information Management, Australian National University, Australia
}

\begin{abstract}
This paper reports exploratory research into the role of the Internet in marketing communications and the conceptualisation of integration and interactivity in this context. Three mini case studies of large companies in the fast moving consumer good industry illustrate the application of frameworks developed for the understanding of integration and interactivity. The case studies show uncertainty about the value of the Internet as a communications channel and the use of interactive tools. The more advanced companies exhibit greater integration of communication tools, across marketing functions and across media. The interactive tools/goals framework developed shows how the more advanced companies also use interactive tools that address a wider range of human motivational goals. This framework suggests how opportunities for value-adding through interactive tools can be identified, giving a basis for further work.
\end{abstract}

\section{INTRODUCTION}

The Internet has emerged as a significant new business tool with considerable implications for marketing communications (Cross 1994). The potential benefits of Internet marketing communication are many. Communications can be one-to-one or many-to-many, synchronous or asynchronous, and local or global. Variable costs tend to zero. There are exciting opportunities for creativity and innovation.

A number of challenges, however, accompany these opportunities. First, knowledge of how to use the Internet in marketing communications is limited. Managers are still grappling with how to use this new medium

The original version of this chapter was revised: The copyright line was incorrect. This has been corrected. The Erratum to this chapter is available at DOI: 10.1007/978-0-387-35692-1_36 
effectively, despite widespread adoption by both marketers and consumers (Berthon et al. 1996; Bush 1998). Second, use of the Internet has not been well integrated with existing marketing practice (Schultz 1999; Sheehan 2001). Evidence suggests the use of the Internet in marketing communications has been stand alone and haphazard in nature. Third, although interactivity is seen as crucial to effective use of the Internet (Ghose and Dou 1998; Perman 2001), it has not been well used (Bucy et al. 1999; Geiger and Martin 1999; Ha and James 1998; Perry 2000).

These challenges have led us to three questions:

1. What is the role of the Internet in marketing communications? How are organizations using the Internet in their promotional mix in practice and how they should be using it?

2. How should Internet communications be integrated into an organization's promotional mix to achieve maximum impact?

3. How are organizations using Internet interactivity in their promotional mix efforts?

We propose that understanding of the two concepts, integration and interactivity, are crucial to effectively using the Internet in the promotional mix. We explore each of these concepts in detail.

First, we draw on work in Integrated Marketing Communications (IMC) to provide a theoretical framework to aid in understanding how the Internet can be integrated into the promotional mix. IMC suggests that if Internet communications are integrated with other marketing communications, then synergies will enhance the effectiveness and efficiency of marketing efforts.

Second, we consider the concept of interactivity as a defining aspect of the Internet and as crucial to the effective use of the Internet in the promotional mix. In understanding interactivity, we consider perspectives from psychology, marketing, human communication, and human-computer interaction. A framework for classifying interactive tools in terms of user's motivational needs is developed as a means of showing how interactivity can add value to users' experiences and to marketing communications.

Our study is exploratory. We found it necessary to consider the issues addressed here as a prelude to more wide-scale work The work is significant as prior literature that addresses the challenges of the use of the Internet in marketing communications in a holistic and systematic way is sparse (Berthon et al. 1996; Watson et al. 2000). Key issues of integration and interactivity have been explored to a limited extent (Gallaher, Foster and Parson 2001, Sheehan and Doherty 2001).

The paper proceeds with a review of relevant literature and the development of conceptual frameworks for the understanding of integration and interactivity. Our analytic frameworks were used in the analysis of marketing communications in mini case studies of three organizations. The 
results of the study are then discussed, with implications for marketing theory and practice.

\section{CONCEPTUAL BACKGROUND}

The marketing literature contains a number of studies that explore the implications of the Internet for marketing (Balasubramanian and Bronnenberg 1997; Barwise et al. 2001; Peterson et al., 1997, Hoffman and Novak 1996; Quelch and Klein 1996). Several studies consider the marketing communications impacts of the Internet (Berthon, Pitt and Watson 1996; Bush et al. 1998; Bush and Bush 2000; Cross 1994; Deighton 1997, Van Doren, Fechner and Green-Adelsberger 2000). Others have begun to apply established marketing theories to the online environment (for example, Bruner and Kumar 2000; Chen and Wells 1999).

This paper considers the impact of the Internet on the promotional mix of an organization's marketing efforts. The promotional mix is that aspect of marketing that relates to a firm's communications with its customers in the hope of influencing the recipient's feelings, beliefs or behaviour. It includes five promotional functions: advertising, direct marketing, sales promotion, personal selling, and public relations (Kotler et al. 1998, Belch and Belch 2001).

To date, advertising has been the major focus of the Internet marketing communication literature. This focus ignores many other forms of Internet marketing communication, such as online communities (Bickart and Schindler 2001; McWilliam 2000), permission-based email (Krishnamurthy 2001), online branding (Davis et al. 2000), chat and discussion groups. No prior studies have been identified that consider these disparate areas of Internet marketing communications in a holistic and systematic way. When Internet marketing communications is approached from this holistic perspective, two issues emerge of central importance - integration and interactivity.

\subsection{Integrated Marketing Communication (IMC)}

A considerable body of IMC literature exists. IMC is a concept of best practice that seeks to integrate all communication activities of an organization in order to achieve enhanced efficiency and effectiveness of communications efforts. IMC has received widespread support by marketers, academics and advertising agencies (Cornelissen and Lock 2000; Gould 2000).

IMC has been defined as: 
A concept of marketing communications planning that recognizes the added value of a comprehensive plan that evaluates the strategic roles of a variety of communications disciplines (for example, general advertising, direct response, sales promotion, and public relations).... and combines these disciplines to provide clarity, consistency and maximum communications impact (Schultz, 1993).

IMC encompasses the dimensions of strategic and tactical integration (Sheehan and Doherty 2001). Strategic integration occurs when the objectives of marketing communications are integrated. This means that all communications are moving in the same direction. For example, an advertisement aiming to increase awareness could be complemented by public relations aimed at this same goal. Tactical integration occurs when the elements of tools, such as pictures and colours, are integrated. Strategic integration cannot occur without tactical integration.

Low (2000) measured integration using the concept of consistency. He suggests IMC can be conceptualised as a continuum on which the degree of consistency is measured using three components: (i) the extent to which communications are planned by the same manager (ii) the strategic consistency of communications efforts, and (iii) the commonality of the communications message.

We propose that, to maximise the impact of the Internet in marketing communications, it should be included in the IMC framework. To do this there must be a clear understanding of how the Internet is conceptualised in marketing. Is it a new communications channel or media, or is it a new marketing function?

There is acceptance of the Internet as a new communications channel, similar to television or radio (Hanson 1998; Hochhauser 2000; Wells et al. 2000). Key characteristics of the media have been identified. These characteristics include consumer control, consumer choice, and interactivity (Hoffman and Novak 1996). In addition, there can be any-to-any communication, the content can be perpetually fresh, consumers can select information, communities can form unbounded by space or time, privacy and identity can be refined, and hyper-impulsivity is enabled (Deighton and Barwise 2000). It is thought that best practice use of Internet marketing will involve leveraging the unique characteristics of this new media, such as interactivity.

At times, however, the Internet is referred to as a new "communications function", similar to sales promotion, or advertising (Belch and Belch, 2001; Ritson, 1998). It appears preferable to avoid this usage, and adopt the view which recognizes the Internet as an alternative channel of communication for existing recognized communication functions. This view allows the development of the framework shown below. 


\subsection{An Internet-Integrated Marketing Communications Framework}

To conceptualise the inclusion of the Internet into integrated marketing communications theory, we propose the framework shown in Table 1. The five promotional functions are in the vertical columns. Definitions for each function are given in the Appendix. Promotional channels, including traditional media and Internet media, form the rows of the table. Channels are the means of distributing the promotional functions. For example advertising (a function) is often screened on television (a channel). Different promotional tools are listed in each cell in the table. These tools represent the diversity of applications, execution and creativity possible in marketing communications.

\begin{tabular}{|c|c|c|c|c|c|}
\hline \multirow[t]{2}{*}{ Channels } & \multicolumn{5}{|l|}{ Functions } \\
\hline & Advertising & $\begin{array}{l}\text { Sales } \\
\text { Promotion }\end{array}$ & $\begin{array}{l}\text { Public } \\
\text { Relations }\end{array}$ & $\begin{array}{l}\text { Personal } \\
\text { Selling } \\
\end{array}$ & $\begin{array}{l}\text { Direct } \\
\text { Marketing }\end{array}$ \\
\hline $\begin{array}{l}\text { Traditional } \\
\text { (Broadcast, } \\
\text { Print, } \\
\text { Supple- } \\
\text { mentary) }\end{array}$ & $\begin{array}{l}\text { Many tools } \\
\text { (magazine, } \\
\text { newspaper, } \\
\text { television } \\
\text { advertisements) }\end{array}$ & $\begin{array}{l}\text { Samples } \\
\text { Coupons } \\
\text { Sweepstakes } \\
\text { Rebates } \\
\text { Refunds } \\
\text { Price-offs } \\
\text { Bonus packs } \\
\text { Frequency } \\
\text { programs } \\
\text { Event marketing } \\
\text { Premiums }\end{array}$ & $\begin{array}{l}\text { Publicity } \\
\text { Sponsorship } \\
\text { Crisis } \\
\text { management } \\
\text { Corporate } \\
\text { advertising } \\
\text { Marketing } \\
\text { Public } \\
\text { relations } \\
\text { Cause-related } \\
\text { marketing } \\
\text { Government / } \\
\text { community } \\
\text { relations }\end{array}$ & $\begin{array}{l}\text { One-to-one } \\
\text { selling }\end{array}$ & $\begin{array}{l}\text { Direct } \\
\text { response ads } \\
\text { Database } \\
\text { marketing } \\
\text { Direct-mail } \\
\text { Mail order } \\
\text { catalogues } \\
\text { Tele- } \\
\text { marketing } \\
\text { Database } \\
\text { CD-Roms } \\
\text { Kiosks } \\
\text { Digital TV }\end{array}$ \\
\hline $\begin{array}{l}\text { Internet } \\
\text { (Web, } \\
\text { Email) }\end{array}$ & $\begin{array}{l}\text { Organizational } \\
\text { website } \\
\text { Banners } \\
\text { Sponsorship } \\
\text { Pop-ups } \\
\text { Push technology } \\
\text { Links from other } \\
\text { websites }\end{array}$ & $\begin{array}{l}\text { Organizational } \\
\text { website with } \\
\text { many of the } \\
\text { above (eg } \\
\text { samples, } \\
\text { coupons, } \\
\text { sweepstakes) } \\
\text { Games } \\
\text { Puzzles } \\
\text { Chat groups } \\
\text { Online } \\
\text { communities }\end{array}$ & $\begin{array}{l}\text { Organizational } \\
\text { website with } \\
\text { many of the } \\
\text { above. } \\
\text { Information } \\
\text { dissemination } \\
\text { tailored to } \\
\text { different } \\
\text { audiences (eg } \\
\text { press packs, } \\
\text { email) }\end{array}$ & $\begin{array}{l}\text { One-to-one } \\
\text { selling } \\
\text { enhanced } \\
\text { with } \\
\text { electronic } \\
\text { information } \\
\text { provision } \\
\text { (online } \\
\text { shopping) }\end{array}$ & $\begin{array}{l}\text { Direct email } \\
\text { Database } \\
\text { marketing } \\
\text { Infomercials } \\
\text { Branding sites } \\
\text { Brand } \\
\text { communities } \\
\text { Permission- } \\
\text { based email }\end{array}$ \\
\hline
\end{tabular}

Table 1. An Integrated Framework for Internet Marketing Communications 
The tools shown in the framework were identified in a review of marketing activities and literature. The lists in each cell are representative rather than exhaustive. In addition, one tool can serve more than one function or purpose.

This framework allows an analysis of the tools used by an organization from the organization's viewpoint. An organization can see which tools it is using for the communications functions in its marketing promotional mix, and which media are, or could be used, to achieve these functions. In addition, this framework allows the level of integration across the promotional mix, both strategic and tactical to be addressed. Ideally, similar strategies would be used across functions (horizontal integration) and across channels (vertical integration).

\section{INTERACTIVITY}

A number of the Internet-based tools in the framework above involve interactivity, which is seen as the key to using the Internet in marketing communications (Ha and James 1998; Hoffman and Novak 1996; Perman 2001; Rogers and Allbritton 1995).

The use of interactivity in marketing communications, however, has not been as successful as hoped (Bucy et al. 1999; Ha and James 1998, Geiger and Martin 1999). One reason could be the lack of common understanding about what interactivity means and what potential it offers.

In the general marketing literature, interactivity has been defined as "a person-to-person or person-to-technology exchange designed to effect a change in the knowledge or behaviour of at least one person" (Haeckel 1998, p.64). Haeckel identifies the dimensions of interactivity as: impact of interaction, number of entities involved, frequency of exchange, degree of contingency, degree of sensory involvement, degree of cognitive involvement, degree of synchronicity, content of exchange, types of entities involved, and type of media involved.

The communications literature uses the analogy of conversation and interpersonal communication to give a feedback view of interactivity. Key to the notion of conversation is the idea of responsiveness. For example, Rafeali (1988, p.111) defines interactivity as:

An expression of the extent that in a given series of communication exchanges, any third (or later) transmission (or message) is related to the degree to which previous exchanges referred to even earlier transmissions. 
The communications in the exchange can be unmediated, as in face-toface interpersonal communication, or mediated through use of media such as the Internet.

Interactivity can be seen, not as a characteristic of the media as some have suggested (Steuer 1992, Hoffman and Novak 1996), but rather a potential that the medium offers. The Internet is a medium that has one of the greatest potentials for interactivity. Rafeali (1988) considers that interactivity exists on a continuum, meaning that there can be high and low levels of interactivity. High levels of interactivity occur when communication relates to previous responses, for example a response from $\mathrm{A}$ to B is based on B's response (Bretz 1983). Low levels of interactivity occur when responses relate to previous exchanges only to a small extent.

The human-computer interaction and other information technology literatures offer further perspectives on the dimensions of interactivity. The dimensions of interactivity identified by Heeter (1989, pp 217-218) include (i) the effort users must exert to access information - that is, "the ration of user activity to system activity", (ii) the complexity of choice available that is, "the extent to which users are provided with a choice of available information" and (iii) responsiveness, or "the degree to which a medium can react responsively to a user". Communication via the Internet is mediated by sophisticated interface design and programming techniques. Knowledge of these is central to effective communication through this medium. Therefore, Internet and interface design principles play an important role in our understanding of interactivity.

Steuer (1992, p. 86) has identified three variables that effect interactivity in mediated communications. "Speed of interaction, or response time, is one important characteristic of an interactive media system". Real time interaction is considered the most sophisticated execution of this variable -for example, the faster the response the more like human interaction. Email is an exception to this rule due to its asynchronous nature. Mapping "refers to the way human actions are connected to actions within a mediated environment". The closer the computer response resembles the natural human response the greater the level of sophistication. Range is "the number of attributes of the mediated environment that can be manipulated and the amount of variation possible within each attribute". These attributes include spatial organisation, colour, and brightness.

Thus, we propose that an understanding of interactivity in Internet communications lies at the intersection of the communications and humancomputer interaction literatures. It involves an appreciation of the different viewpoints expressed above - from both the interpersonal and technological literatures 
Further, we propose that a key to understanding how interactivity is used in marketing communications is consideration of how added value is offered to the user - that is, how interactivity allows fulfilment of basic human goals. Perceived usefulness has been found to be a strong determinant of the adoption and use of information technologies in general (Davis, 1989). This finding has been observed mostly in industry contexts where users were motivated by the need to accomplish a task related to their employment. With the use of the Internet for marketing communications, we have a more general context where users have many goals, including those relating to social needs and entertainment. For this reason, we suggest that interactive experiences in marketing communication should be evaluated against the different human goals they can help satisfy.

A convenient taxonomy of human goals for this purpose is that offered by Ford (1992). This is a general taxonomy, with no hierarchical ordering of goals, where "each category simply describes a particular kind of consequence that people may desire to achieve" (Ford 1992 p.86). Ford groups human goals as follows:

- affective goals (entertainment, tranquillity, happiness, bodily sensations, physical well-being.),

- cognitive goals (exploration, understanding, intellectual creativity, positive self-evaluations),

- subjective organization goals (unity, transcendence)

- self-assertive social relationship goals (individuality, self-determination, superiority, resource acquisition,

- integrative social relationship goals (belongingness, social responsibility, equity, resource provision), and

- task goals (mastery, task creativity, management, material gain, safety).

The first three goal categories represent within-person goals, and the last three categories represent goals with respect to the relationships between people and their environments. Some goals may, on average, be more compelling than others (eg happiness, physical well-being, belongingness). At this point, we do not consider the relative importance of the goals or categories, though this area could warrant further research in Internet marketing, particularly in respect to which goals motivate particular demographic groups.

The application of both the Internet-integrated marketing communications and the interactivity/tools frameworks is illustrated in the following sections in the analysis of case studies. 


\section{METHOD}

Our exploratory research involved three mini case studies of large companies in the fast moving consumer goods (FMCG) industry. This industry was selected because it tends to use the Internet for marketing communications (rather than, for example, service or distribution). The three organisations chosen were selected because they appeared to be at different stages in their use of Internet communications. Each organisation operates in Australia, marketing multiple consumer product brands.

The OzProd company is the least advanced in the use of Internet marketing communications. EuroNat is using the Internet for Internet marketing communications activities, but does not attach a great deal of importance to these efforts. OctoPlus has been using the Internet for more than five years, is committed to Internet communications and is quite sophisticated in their use. Pseudonyms are used and only limited details given for each organisation for privacy reasons.

Data was gathered in interviews with marketing or marketing communications managers from each of these organisations. In addition, data was gathered from secondary sources including company websites and annual reports.

Interviews were conducted by telephone and lasted about 30 minutes. A standard set of open-ended questions guided the interviews ${ }^{9}$. The questions focused on three areas - the role of the Internet, integration and interactivity. Interview transcripts were prepared following each interview.

In addition, an analysis of each organization's web sites was performed, using the interactive tools/goals framework outlined above.

\section{RESULTS}

The results of the mini case studies are presented in terms of our three research questions.

\subsection{Role and Use of the Internet in Marketing Communications}

Table 2 gives an overview of how each case study organization is using the Internet.

\footnotetext{
${ }^{9}$ The interview guide is available from the authors on request.
} 
Respondents confirmed the view of the Internet as a communications channel, or another prong in the fork in reaching the consumer.

The Internet was seen as a support media and secondary to traditional media such as television. For OzProd and EuroNat, Internet communications were a relatively low priority. OctoPlus placed more importance on the Internet, considering that it builds value above the mainstream media.

\section{OzProd}

OzProd is a large Australian-based food company at the first stages of using the Internet in its marketing communications. The company recognizes that the Internet has been the last on our list. Some brands have websites, but many are out of date and have not been upgraded from initial versions. A corporate web page is used for the community and investors, with annual reports and consumer feedback sections. Links to brand sites were difficult to find on the corporate website. The company is considering putting a freeze on Internet communications apart from one or two sites until they can be relaunched.

Long-term we see the Internet as having a large role, especially for one-to-one relationships. It can communicate a depth of information and enable a direct dialogue with consumers.

\section{EuroNat}

EuroNat is a very large international food company and an umbrella brand for many consumer product brands. The Internet is used in a range of ways, including corporate and brand websites, product launches, competitions/promotion, market research and Internet advertising. Websites are targeted to specific audiences, such as children. Brand websites are closely linked to brand positioning. The corporate website serves multiple stakeholders and contains clear links to brand websites. Online and offline communications are well integrated, for example product packaging and some sales promotions carry website addresses. Many interactive tools are used.

The Internet is a communication tool to be evaluated against objectives. It allows direct and dynamic communication with customers. It is another media - its use depends on the situation, objectives and target market.

\section{OctoPlus}

OctoPlus is a very large international, branded, consumer goods company. It has been using Internet marketing communications in Australia for over five years. Unlike EuroNat, OctoPlus is not an umbrella brand and is hence invisible to the consumer. Websites are the main form of communication and are used where they add value for the consumer and the organisation. The focus is on using Internet communications to achieve specific objectives. These include building brand equity, relationships, promotions, customer contact, support programs, and advertising.

Advertising on the Web is a way of extending our reach to a different group of people in a cost-effective way. It is especially good for hard-to-get-at consumers like kids who use technology a lot. We use the Internet to build brand equity and build relationships - not for selling. We have a website set up to support [a safety campaign]. It is purely about completing a link in a community service.

Table 2. Internet use in marketing communications.

The Internet was not seen as a new, distinct, promotional function. However, several existing promotional functions were fulfilled through the 
Internet. These were advertising, sales promotion, and public relations. Direct marketing on the Internet was not used. Interest existed in using the Internet for direct marketing in the future. For example, OctoPlus uses sales promotions to collect customer information. This information is used to build a database with the intention of using it for direct marketing in the future. There was no personal selling online, which is not surprising for FMCG industries.

Relationship marketing and branding were seen as particularly important. For example, OzProd noted the Internet's potential for one-to-one communications, and EuroNat highlighted the Internet's facility to communication a depth of information - both important in building relationships. All respondents had brand websites and advanced companies, such as OctoPlus, used the Internet to create positive brand experiences. A key issue for respondents was the value proposition of this new media in their communication efforts. Respondents were grappling with how the Internet could add value to both the consumer and its business. For example EuroNat wanted to know: How does the Internet affect customer attitudes or intentions to purchase?

\subsection{Integration of the Internet in the Promotional Mix}

Our second research question focused on how the Internet should be included in the promotional mix for maximum impact. Respondents were unanimous that the best way to include the Internet in the promotional mix was to integrate it. However, implementation did not match these views in all cases.

Integration in this study was assessed using the concept of consistency. Three measures of integration were used (Low, 2000):

- Planning/Management: In all case online and offline communication efforts were planned by the same manager.

- Strategic consistency: Marketing communications were strategically integrated at OctoPlus and EuroNat. However the marketing communications of OzProd were not strategically consistent.

- Commonality of messages: OctoPlus and EuroNat had consistent communications messages, while OzProd did not.

An additional dimension was highlighted in the study, termed brand positioning. This is consistent with the marketing literature (e.g. Shultz, 2001). Respondents commented that Internet communications should be consistent with the positioning of the brand. For example, OctoPlus said the Internet should live, breath and enhance that brand's proposition. EuroNat and OctoPlus integrated their Internet communications with brand 
positioning. OzProd's Internet communications did not reflect brand positioning.

Table 3 summarizes the results concerning the integration of the Internet in the promotional mix in the organizations studied. Overall, OzProd did not integrate, keeping the Internet distinct from other promotional activities. EuroNat integrated the Internet with other promotional activities, but was unsure about how it should be included and was still experimenting in this area. The Internet was seamlessly included in OctoPlus's promotional mix and used wherever it could add value.

\begin{tabular}{|l|c|c|c|c|}
\hline & Same manager & Same message & $\begin{array}{c}\text { Strategic } \\
\text { consistency }\end{array}$ & $\begin{array}{c}\text { Brand } \\
\text { positioning }\end{array}$ \\
\hline OzProd & $\mathrm{x}$ & - & - & - \\
\hline EuroNat & $\mathrm{x}$ & $\mathrm{x}$ & $\mathrm{x}$ & $\mathrm{x}$ \\
\hline OctoPLus & $\mathrm{x}$ & $\mathrm{x}$ & $\mathrm{x}$ & $\mathrm{x}$ \\
\hline
\end{tabular}

Table 3. Integration of the Internet in the promotional mix in the case study organizations

The constructs of strategic and tactical integration were clarified by respondents. These marketing managers believed that strategic integration involved integrating brand positioning and communications strategy. Integrating communication message and creativity was considered tactical integration. Tactical integration was found in all organisations, except OzProd.

Respondents were not questioned directly in terms of the IMC Framework shown in Table 1. It was clear from their comments, however, that they distinguished among the different functions in the promotional mix and were aware of how different Internet tools could be used to address these functions individually:

If we're target marketing we use the Internet for banner advertising and building awareness. [EuroNat]

The best role at the moment for the Internet in marketing communications is in sales promotion. [OctoPlus]

Respondents believed that use of the Internet should be integrated across the tools in Table 1. Verbatim comments show the flavour of responses.

The Internet should be integrated. [OzProd]

Every piece of communication to consumers communicates a similar message. For example, for [a product] the TV and Web site relate to [concept]. Communications should be integrated. There should be horizontal and vertical consistency. Strategic integration is the same brand positioning across media and tools. [EuroNat] 
We integrate where it's relevant. It's beyond the stage where every product needs a Web site. ... At the end of the day the user expects a similar brand experience. All communications are signed off by the marketing manager. [OctoPlus]

Overall, responses showed that companies direct energy at integration across communication tools, or cells within the framework in Table 1, though not all have achieved this. The concept of "branding" occurred frequently and was seen to be of considerable importance.

\subsection{Interactivity}

The third research question concerned the use of Interactivity. Responses showed varying conceptualisations of interactivity.

We don't use interactivity.... [but also commented] With [one of our products] consumers can get recipes, communicate with home economists and get nutritional information. [OzProd]

Interactivity means consumers communicating with your site. Not just receiving messages but doing something... It is a small priority with us at the moment, because we haven't identified reasons for interactivity - in terms of cost. Why is interactivity better for a company that sells products below $\$ 10$ than billboards or other media? However, we are not ignoring it because of its potential in market research and relationships. Kids and teens especially expect a good web site. It comes down to business case decisions. Still, interactivity is an empowering tool for consumers. Consumers can turn it off, whereas with TV we yell at them. We are still experimenting and learning. Getting used to consumers and learning how not to be flicked... Why use interactivity for a product like [a food bar]? Are banner ads relevant? [EuroNat]

We see interactivity as a fully integrated part of the mix to enable us to interact with customers. It gives us the ability to reinforce brand propositions. ... There are very few examples of effective use, though banks are a great example.. depends on the industry. Creativity means it is still totally open. [OctoPlus]

To analyse the uses of interactivity, we used a framework based on Ford's goal taxonomy as reviewed earlier. Table 4 shows both the analysis framework and the analysis of the three case studies. The first two columns in Table 4 show how different interactive web tools can be grouped against the different motivating goals, and form a framework for analysing an organization's Internet tools. The two social relationship goals have been merged. This framework allows the analysis of interactive Internet tools from the user's viewpoint. Some interactive tools (email and search) are so general that they can be used in achievement of almost any goal, so are grouped separately. Other tools could also be used to achieve a number of 
goals, and we have included them in the categories where they appear to be of primary use. Ford considers that behaviour is often (perhaps usually) guided by multiple goals simultaneously, so it recognized that this classification mechanism is somewhat arbitrary. We could find no tools that clearly addressed the "subjective organization goals" of unity and transcendence. Ford considers that the "exquisitely powerful and satisfying state of 'flow', as described by Csikszentmihalyi (1990) in his theory of optimal experience" exemplifies a kind of transcendent state to which one might aspire. These flow states could occur with a number of interactive experiences, such as searching for information for pleasure or work tasks under certain conditions.

\begin{tabular}{|c|c|c|c|c|}
\hline & & \multicolumn{3}{|c|}{ Organizational usage } \\
\hline Goal Category & Interactive tools & OzProd & EuroNat & OctoPLus \\
\hline $\begin{array}{l}\text { Affective goals } \\
\text { (entertainment, tranquillity, } \\
\text { happiness, bodily sensations, } \\
\text { physical well-being.) }\end{array}$ & $\begin{array}{l}\text { Promotions } \\
\text { Virtual-tour } \\
\text { Downloads } \\
\text { Games } \\
\text { Film }\end{array}$ & & $\begin{array}{l}X \\
X \\
X\end{array}$ & $\begin{array}{l}X \\
X\end{array}$ \\
\hline $\begin{array}{l}\text { Cognitive goals } \\
\text { (exploration, understanding, } \\
\text { intellectual creativity, positive } \\
\text { self-evaluations) }\end{array}$ & $\begin{array}{l}\text { Puzzles } \\
\text { Games } \\
\text { In-depth information } \\
\text { provision }\end{array}$ & & & $X$ \\
\hline $\begin{array}{l}\text { Subjective organization goals } \\
\text { (unity, transcendence) }\end{array}$ & $\begin{array}{l}\text { Many tools under } \\
\text { specific conditions }\end{array}$ & $?$ & $?$ & $?$ \\
\hline $\begin{array}{l}\text { Self-assertive and integrative } \\
\text { social relationship goals } \\
\text { (individuality, self- } \\
\text { determination, superiority, } \\
\text { resource acquisition, } \\
\text { belongingness, social } \\
\text { responsibility, equity, } \\
\text { resource provision) }\end{array}$ & $\begin{array}{l}\text { Communities } \\
\text { Chat } \\
\text { Members' sections }\end{array}$ & & $\mathrm{X}$ & $\begin{array}{l}X \\
X \\
X\end{array}$ \\
\hline $\begin{array}{l}\text { Task goals } \\
\text { (mastery, task creativity, } \\
\text { management, material gain, } \\
\text { safety) }\end{array}$ & $\begin{array}{l}\text { Input-response } \\
\text { E-forms } \\
\text { Downloads } \\
\text { Calculators } \\
\text { Members' sections } \\
\text { Store locator } \\
\text { Promotions } \\
\text { Customisation and } \\
\text { personalisation } \\
\text { Websites that change } \\
\text { behaviour }\end{array}$ & & $\begin{array}{l}X \\
X \\
X \\
X\end{array}$ & $\begin{array}{l}\mathrm{X} \\
\mathrm{X} \\
\mathrm{X} \\
\mathrm{X} \\
\mathrm{X}\end{array}$ \\
\hline (All goals) & $\begin{array}{l}\text { Search } \\
\text { Email }\end{array}$ & $\begin{array}{l}\mathrm{X} \\
\mathrm{X}\end{array}$ & $\begin{array}{l}\mathrm{X} \\
\mathrm{X}\end{array}$ & $\begin{array}{l}\mathrm{X} \\
\mathrm{X}\end{array}$ \\
\hline
\end{tabular}

Table 4. Application of interactive tools/goals framework to marketing communications 
Note that Ford's taxonomy of human goals offers a more extensive categorization of possible human-goal states in the Internet environment than offered previously. Hoffman and Novak (1996), for example, differentiated primarily between "experiential" and "goal-directed" behavior in their landmark work on marketing on the Web. Their interest was primarily in the state of "flow" (Csikszentmihalyi, 1977, 1990).

The last three columns in Table 4 shows the analysis of the case studies using the framework. The websites of the three case study companies were analysed in terms of the interactive tools each company was using. This analysis was performed by the first author. Interactive tools were used mainly to fulfill task, affective and social relationship goals. Interactive applications were available most in task-based situations -- for example, finding prices. Entertainment and social relationship goals were the next most frequent applications available. OzProd used few interactive tools. EuroNat and OctoPlus each made numerous interactive tools available. Note that no attempt was made to classify company's usage of tools in terms of "Subjective organizational goals", as achievement of these goals (eg through "flow") is likely to be very highly subject- and context-dependent.

\section{CONCLUSION}

We have reported exploratory research on the role of the Internet in marketing communications and the conceptualisation of integration and interactivity in this context.

Three mini case studies of large companies in the fast moving consumer good industry has allowed some grounding of our ideas on how to approach our research questions.

In answer to our first research question, the role of the Internet in marketing communications was seen to be to provide an additional communication channel for functions in the marketing mix. The three companies studied were using the Internet mainly for advertising, sales and public relations. For this industry, personal selling is not a priority. There was interest in direct marketing in the future. Relationship marketing and branding were seen as particularly important. A key issue for respondents was the value proposition of this new media in their communications efforts.

In answer to the second question, integration was believed to be important in all three companies. Respondents believed that all communication messages should be integrated, including those on the Internet. Integration through brand positioning was identified as a dimension of integration, in addition to the three consistency dimensions identified a priori from the literature. The least advanced company had integration only 
in the sense that the same manager planned all marketing communications. The two more advanced companies were also integrated in terms of strategic consistency and commonality of messages. The integrated-Internet Marketing communications Framework developed for this study (Table 1) gave a conceptual background to our questioning of integration. This framework identifies tools used in marketing communications in terms of the marketing functions achieved. Thus, in some respects it gives a push viewpoint.

Our third research question asked how organizations are using interactivity. Interactivity has a number of conceptualisations, depending on the discipline in which it is studied. It appears to be important to maintain a cross-disciplinary view, so that the different dimensions of interactivity are appreciated. Our three case study organizations had different views on interactivity and were unclear as to its value and how it should be used most effectively. An analysis in terms of our interactive tools/goals framework showed the most advanced company was using tools to address the largest spread of human motivational goals, while the next most advanced company was not far behind. The least advanced company had interactive tools that addressed the fewest of users' possible motivational goals. This tools/goals framework categorizes Internet communication tools in terms of user's goals. Thus, in some respects it gives a pull viewpoint.

Though our work is exploratory it raises some interesting issues for future work. Organizations were seen to be uncertain about how the Internet, and interactive tools in particular, can add value. We suggest that the tools/goal framework can assist in identifying possible opportunities for use of interactive tools, particularly if the goals of particular demographic groups can be isolated. Our analysis showed that even the advanced companies were not using many tools in some goal categories - for example, for cognitive goals such as exploration and understanding. Demographic groups who are likely to have these goals may be reached more readily by tools in this category. The achievement of subjective organization goals, such as "flow", presents a further challenge, but may bring greater rewards.

In addition, it is interesting to compare the Internet tools in the "push", marketing-oriented framework (lower half of Table 1) against the "pull", consumer-goal oriented framework (left two columns of Table 4). Some tools, such as banner ads, do not appear in the latter framework and it is difficult to see which, if any, consumer goals they fulfil. One interviewee commented: Are banner ads relevant? It appears that in the Internet environment, non-passive, "consumer-pull", interactive marketing tools have the greatest potential to add value because of the additional range of human goals they can address. 


\section{REFERENCES}

Barwise, P. Elberse, A. Hammond, K. (2001) Marketing and the Internet. London Business School.

Belch, G.E. Belch, M.A (2001) Advertising and Promotion - An integrated marketing communications perspective. $5^{\text {th }}$ ed. McGraw-Jill Irwin: San Francisco

Berthon, P. Pitt, L.F. Watson, R.T. (1996). The world wide web as an advertising medium: towards an understanding of conversion efficiency. Journal of Advertising Research. Vol.36 No.1 pp.43-54

Bretz, R. (1983) Media for Interactive Communication. Sage: Beverly Hills

Bezjian-Avery, A. Calder, B. Iacobucci, D. (1998) New Media Interactive Advertising vs. Traditional Advertising. Journal of Advertising Research. Vol.38 No.4; pp. 23-33

Blattberg, R.C. Deighton, J. (1991) Interactive marketing: exploiting the age of addressability. Sloan Management Review. Fall pp.5-14

Bickart, B. Schindler, R.M. (2001) Internet Forums as influential sources of consumer information. Journal of interactive marketing. Vol.15 No.3

Bruner, G. C. Kumar, A. (2000) Web commercials and Advertising Hierarcy of Effects. Journal of Advertising Research. Vol.40 No.1/2. pp.35-43

Bucy, E.P. Lang, A. Potter, R.F. Grabe, M..E. (1999) Formal features of cyberspace: relationships between web page complexity and site traffic. Journal of the America society for information science. Vol. 50 No. 13. pp.1246-1256

Bush, A.J. Bush, V. Harris, S. (1998) Advertiser perceptions of the Internet as a marketing communications tool. Journal of Advertising research. Vol.38 No.2 pp.17-27

Bush, A.J. Bush, V.D (2000) Potential Challenges the Internet Brings to the agency-advertiser relationship. Journal of Advertising Research. Vol.40 No.4; pp.7-16

Chen, Q. Wells, W.D. (1999) Attitude toward the site. Journal of Advertising Research. Vol.39 No.5 pp.27-38

Cornelissen, J.P. Lock, A.R. (2000) Theoretical Concept or Management Fashion? Examining the significance of IMC. Journal of Advertising Research. Vol.40 No. 5 pp.7-15

Covielo, N. Milley, R. Marcolin, B. (2001) Understanding IT enable interactivity in contemporary marketing. Journal of Interactive Marketing. Vol.15 No.4 pp.18-33.

Coyle, J. R. Thorson, E. (2001) The effects of progressive levels of Interactivity and vividness in web marketing sites. Journal of Advertising. Vol.30 No.3 pp.65-77

Cross, R. (1994) Internet: The missing Marketing Medium Found. Direct Marketing. Vol.57 No.6 pp.20-24

Csikszentmihalyi, M. (1977). Beyond boredom and anxiety. San Francisco: Jossey-Bass.

Csikszentmihalyi, M. (1990). Flow: The psychology of optimal experience. New York: Harper Row.

Davis, F. D. (1989). Perceived usefulness, perceived ease of use, and user acceptance of information technology. MIS Quarterly, Sept., 319-340.

Davis, R. Buchanan-Oliver, M. Brodie, R.J. (2000) Retail Service Branding in Electronic Commerce environments. Journal of Services Research. Vol.3 No.2; pp.178-187

Deighton, J. Barwise, P. (2000) Digital Marketing Communication. Future Media Research Programme - London Business School.

Deighton, J. (1997) Commentary on "Exploring the implications of the Internet for consumer marketing. Journal of the Academy of Marketing Science. Vol.25, No.4, pp.329-346

Duncan, T. R. Everett S. E. (1993) Client perceptions of Integrated Marketing Communications. Journal of Advertising Research. Vol.33 No.3; pp.30-40 
Ford, M. (1992). Motivating Humans Goals, Emotions \& Personal Agency Beliefs. Sage Publications: London

Geiger, S. Martin, S. (1999) The Internet as a relationship marketing tool - some evidence from Irish companies. Irish Marketing Review. Vol.12 No.2 pp.24-36

Ghose, S. Dou, W. (1998) Interactive Functions and their impacts on the appeal of Internet presence sites. Journal of Advertising Research. Vol.38 No.2; pp.29-44

Gould, S.J (2000) The state of IMC research and applications. Journal of Advertising Research. Vol. 40 No.5 pp.22-24

Haeckel, S. H. (1998). About the nature and future of interactive marketing. Journal of Interactive Marketing, 12(1), pp. 63-71.

Hanson, W. (1998) The original WWW: Web lessons from the early days of radio. Journal of Interactive Marketing. Vol.12 No.3 pp.46-56

Heeter, C. (1989) Implications of new interactive technologies for conceptualizing communication. In J.L. Salvaggio \& J. Bryant (Eds.) Media use in the information age (pp.217-236). Hillsdale, NJ: Lawrence Erlbaum.

Hochhauser, R.M. (2000) The interactive evolution of a direct marketing leader. Direct Marketing. Vol.63 No.1 pp.45-49.

Hoffman, D.L. Novak, T.P. (1996) Marketing in Hypermedia Computer-Mediated Environments: Conceptual Foundations. Journal of Marketing. Vol.60 No.3 pp.50-68.

Kotler, P. Armstrong, G. Brown, L. Adam, S. (1999) Marketing $4^{\text {th }}$ edition. Prentice Hall: Australia.

Krishnamurthy, S. (2001) A comprehensive Analysis of Permission Marketing. Journal of Computer Mediated Communication. Vol.6 No.2

Low, G.S. (2000) Correlates of Integrated Marketing Communications. Journal of Advertising Research. Vol.40 No.3 pp.27-35

Mcgaughey, R.E. Mason, K.H. (1998) The Internet as a marketing tool. Journal of Marketing Theory and Practice. Vol.6 No.3 1998. pp.1-11.

McWilliam, G. (2000) Building Stronger Brands through Online Communities. Sloan Management Review. Vol.41 No.3 pp.43-55

Perman, S. (2001) Enterprise Marketing, Building Brands. Asia week. Oct 262001.

Perry, M. Bodkin C. (2000) Content analysis of Fortune 100 company websites. Corporate Communications. Vol.5 No.2 pp.87-96

Peterson, R.A. Balasubramanian, S. Bronenberg, B. J. (1997) Exploring the implications of the Internet for consumer marketing. Journal of the Academy of Marketing Science. Vol.25 No.4, pp.329-346

Quelch, J.A. Klein, L.R. (1996) The Internet and International Marketing. Sloan Management Review. Vol.37 No.3 pp.60-76

Rafaeli, S. (1988) Interactivity: From New Media to Comunication. In: Advances in Communication Science, Merging Mass and Interpersonal Processes. Hawkins, R.P., Wieman J.M, and Pingree S. eds. Sage: Newbury Park, CA. 110,34

Rogers, E.M. Allbritton, M.M (1995) Interactive Communication Technologies in Business Organisations. The Journal of Business Communication. Vol.32. No.2. pp.177-195

Sheehan, K.B. Boherty, C. (2001) Re-weaving the web: Integrating Print and Online Communications. Journal of Interactive Marketing. Vol.15 No.2 pp.47-59

Schlosser, A.E. Shavitt, S. Kanfer, A. (1999) Survey of Internet Users Attitudes towards Internet Advertising. Journal of Interactive Marketing. Vol.13 No.3 pp.34-54

Schultz, D.E. (1993) Integrated Marketing Communications: Maybe definition is in the point of view. Marketing News. Vol.27 No.2 pp.17-18 
Schultz, D.E. (1999) New media, old problem: Keeping marcom integrated. Marketing News. Vol.33 No.7 pp.11-12

Schultz, D.E. (2001) The core of integration is the brand. Marketing Management. Vol.10 No. 1 pp. $6-8$

Steuer, J. (1992) Defining virtual reality: dimensions determining telepresence. Journal of Communication. Vol 42 No 2. pp.73-93

Takacs, S.J. Freiden, J.B. (1998) Changes on the Electronic Frontier: Growth and opportunity of the World Wide Web. Journal of Marketing Theory and Practice. Vol.6 No.3 pp.24-38

Ritson, M. (1998) Three possibilities in integrating the Internet. Marketing News. Vol. 32 No.10. pp.10-11.

Van Doren, D.C. Fechner, D.L. and Green-Adelsberger, K. (2000) Promotional Strategies on the World Wide Web. Journal of Marketing Communications. Vol.6 pp.21-35

Wells, W. Burnett, J. Moriarty, S. (2000) Advertising principles and practice $5^{\text {th }}$ ed. Prentice Hall: New Jersey

Watson, R.T. Zinkhan, G.M. Pitt, L.F. (2000) Integrated Internet Marketing. Communications of the AMC. Vol.43 No.6 pp.97-102

\section{APPENDIX}

- Definition of Promotional Functions:

(source: Belch and Belch 2001)

Advertising is any paid form of non-personal communication about an organization, product, service, or idea by an identified sponsor.

Direct marketing is where organizations communicate directly with target customers to generate a response and/or a transaction.

Sales promotion is marketing activities that provide extra value or incentives to the sales force, distributors, or the ultimate consumer and can stimulate immediate sales.

Personal selling is a form of person-to-person communication in which a seller attempts to assist and/or persuade prospective buyers to purchase the company's product or service or to act on an idea.

Public relations is the management function which evaluates public attitudes, identifies the policies and procedures of an individual or organization with the public interest, and executes a program of action to earn public under-standing and acceptance. Publicity refers to non-personal communications regarding an organization, product, service, or idea not directly paid for or run under identified sponsorship. 